\title{
'n Verrassende perspektief en verklaring van Openbaring
}

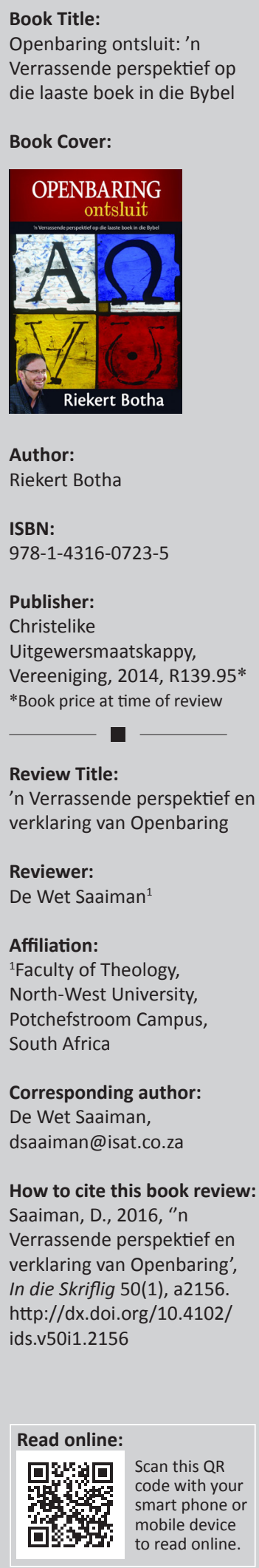

Die laaste Bybelboek, Openbaring, is vir die deursnee Bybelleser 'n groot uitdaging en dikwels verwarrend. Hoe moet ons die boek verstaan? Hoe moet ons die simboliek en beelde wat daarin gebruik word, verklaar? Hoe kan ons Openbaring met sy betekenisverskille, vreemde vertalings en nog vreemder uitdrukkings vir die hedendaagse Bybelleser toeganklik maak? Teoloë het nie almal die vermoë om die boek Openbaring aan te pak en dit op so 'n wyse aan te bied dat dit vir 'n mens meer toeganklik is en daardeur uiteindelik ontsluit word nie. Riekert Botha slaag egter uitstekend daarin om Openbaring op 'n vars, en in sy eie woorde, op ' $n$ 'verrassende manier' aan te bied.

Botha doen dit deur aan te dui dat Openbaring, hoe onverstaanbaar dit ook al mag wees, wel verstaan kan word. Hy stel voor dat 'n hermeneutiese sleutel tot die uitleg van die boek Openbaring gevolg moet word. Die volgende hermeneutiese vrae moet deurlopend gevra word wanneer 'n mens met die teks van die Bybel en in die besonder met Openbaring besig is:

- Wie is die oorspronklike ontvangers van die boodskap?

- Wat was die omstandighede waarin hulle geleef het?

- Watter spesiale behoeftes of sake het moontlik tot die skrywe van die boek aanleiding gegee?

- Wat was God se boodskap aan die mense in daardie tydvak met hulle spesiale omstandighede?

Hierdie vrae dien, volgens Botha, as die sleutel tot die ontsluiting en verstaan van Openbaring. Die gebrek aan die behoorlike beantwoording daarvan kan tot ' $n$ waninterpretasie en frustrasie met die stof voorhande lei. Na die behoorlike beantwoording van bogenoemde vrae is 'n mens eers gereed om oor die volgende vraag te besin: Wat is God se boodskap deur Openbaring vandag aan ons?

Botha bespreek die boodskap van Openbaring deur na die eerste ontvangers, die eerste troonvisioen, die boodskap aan die sewe gemeentes en die sewe visioene te kyk. Aan die einde van sommige van die troonvisioene gee die outeur 'n kort opsomming van die inhoud van die betrokke visioen. Dit is duidelik dat Botha homself in Openbaring ingegrawe het en dat hy deeglike navorsing gedoen het om die moeilike stof van die boek vir die gemiddelde leser in 'n verstaanbare idioom duidelik te maak.

Die publikasie is uiteraard nie as 'n diepgaande eksegetiese hulpmiddel tot die verstaan en verklaring van Openbaring bedoel nie. Ek glo Botha se bedoeling met Openbaring ontsluit - ' $n$ Verrassende perspektief op die laaste boek in die Bybel is om Openbaring juis vir die Bybelleser toeganklik te maak wat nie altyd tot al die kommentare en studiemateriaal toegang het wat in 'n teoloog se studeerkamer is nie. Op hierdie punt moet ek byvoeg dat Botha se boek, gemeet aan ander boeke oor Openbaring, 'n bietjie lig bevind kan word. Hy slaag egter daarin om getrou te bly aan die hermeneutiese sleutels wat hy as oogmerk in die verstaan van die boodskap van Openbaring gestel het.

Die teks is tegnies goed versorg en lees maklik. Dit is net jammer dat in die eksemplaar wat ek vir resensering ontvang het, 'n bladsy of twee ontbreek het. Dit doen afbreuk aan die eindproduk, maar nie noodwendig aan die inhoud van die boek nie. Ek het al self die boek in 'n Bybelstudie met vrug gebruik en kan dit met groot vrymoedigheid aanbeveel. Bybelstudiegroepe kan dit ernstig oorweeg om hierdie boek by hulle byeenkomste te behandel sonder om vir die uitdagings daarvan terug te deins. Predikante wat soms self versigtig is om uit Openbaring te preek, kan gerus hierdie publikasie aanskaf om die teks en die verklaring daarvan vir die gemeente op 'n verrassende en nuwe wyse meer toeganklik te maak.

Dit was 'n voorreg om die boek te resenseer. 